\section{Rocznicowe mobilizacje pamięci. Międzypokoleniowe projekty teatralne a trauma kulturowa}

Edyta Lorek-Jezińska

TEKSTY DRUGIE 2018, NR 4, S. 152-169

DOI: $10.18318 /$ td.2018.4.9

\section{Wstęp}

Obchody stuletniej rocznicy I wojny światowej obejmują wiele przejawów mobilizacji pamięci kulturowej i strategii upamiętniania, które można byłoby określić mianem trzeciego boomu pamięci - w nawiązaniu do wcześniejszych dwóch etapów i zarazem rodzajów zaangażowania jednostek i pokoleń w procesy nadawania znaczenia i sensu traumatycznym wydarzeniom wojny. Opisywane przez Jaya Wintera etapy intensyfikacji lub rozkwitu pamięci były zakotwiczone w relacjach pokoleniowych - bezpośredniej reakcji na wydarzenia świeżo zakończonego konfliktu i powrotu do nich młodszej generacji, połączonego z buntem i nowym spojrzeniem na manipulacje ideologiczne wcześniejszego okresu. Mimo że powrót pamięci o I wojnie światowej w dużej mierze był konsekwencją zainteresowania wydarzeniami II wojny i rozpoczął się w okresie obchodów 50-lecia konfliktu, pamięć społeczna, jak twierdzi Winter, miała bezpośrednie zaplecze w postaci historii rodzinnych, w bezpośrednim kontakcie między pokoleniami. W kontekście relacji
Edyta Lorek-Jezińska

- dr hab., kierownik

Zakładu Kultury

Anglojęzycznej w Ka-

tedrze Filologii Angiel-

skiej na Uniwersytecie

Mikołaja Kopernika

wToruniu. Zajmuje

się anglojęzycznym

teatrem i dramatem

współczesnym,

teoriami hauntologii

i traumy, feminizmem

i dramatem niepełno-

sprawnych. Ostatnio

opublikowana mo-

nografia: Hauntology

and Intertextuality in

Contemporary British

Drama by Women

Playwrights (2013).

Kontakt: lorek@

umk.pl 
pokoleniowych stulecie I wojny światowej opiera się na pewnego rodzaju sztucznej mobilizacji relacji pokoleniowych w globalnym wydaniu, której ważnym elementem jest komunikacja za pomocą nowych mediów (projektów i udostępnień internetowych) i budowania powiązań między pamięcią o I wojnie światowej i współczesnym doświadczeniem konfliktu i traumy. Celem niniejszego artykułu jest prześledzenie znaczenia projektów teatralnych i parateatralnych w próbie nawiązania relacji pokoleniowych poprzez udział w rekonstrukcji, przetworzeniu i gotowości przyjęcia roli świadka. Jubileuszowe upamiętnianie traumy wojennej przenosi zarówno indywidualne, jak i zbiorowe doświadczenie wojny z pokolenia na pokolenie, tworząc dynamiczne połączenia ze współczesnymi traumatycznymi doświadczeniami za pomocą aktywnego udziału młodych artystów i widzów. Kontekstem dla dyskusji na temat wybranych teatralnych działań jubileuszowych będą teorie traumy kulturowej i indywidualnej, a w szczególności relacje między stopniami zaangażowania w opowieść pokrzywdzonego i ocalonego.

\section{Trauma kulturowa i pierwsza wojna światowa}

Według definicji Jeffreya C. Alexandra trauma kulturowa dotyczy sytuacji, w której „członkowie zbiorowości czują, że poddani zostali straszliwemu wydarzeniu, pozostawiającemu nieusuwalne ślady na ich grupowej świadomości, na zawsze naznaczającemu ich wspomnienia oraz zmieniającemu ich przyszłą tożsamość w fundamentalny i nieodwracalny sposób"1. W ujęciu psychoanalitycznym trauma zbiorowa pociaga za sobą procesy „wstecznego przepracowania symbolicznych rezyduów, które pierwotne wydarzenie pozostawiło we współczesnej pamięci”2. Celem tego procesu „pozostaje przywrócenie zbiorowego zdrowia psychicznego poprzez zniesienie społecznych represji i przywrócenie pamięci” - cofnięcie represji i „dopuszczenie do wyrażenia zdławionych emocji straty i żałoby"3. W przypadku obchodów setnej rocznicy I wojny światowej afekt związany z pierwotną traumą wydaje się zbyt odległy, aby mógł posłużyć wyrażeniu powstrzymywanych emocji; jednocześnie - ze względu na obecny pluralizm, fragmentację oraz negocjowalność znaczeń w ramach kultury partycypacyjnej - wspomniane wyżej

\footnotetext{
1 J.C. Alexander Trauma kulturowa i tożsamość zbiorowa, w: Znaczenia społeczne. Studia z socjologii kulturowej, przeł. S. Burdziej, J. Gądecki, Nomos, Kraków 2010, s. 195.

2 Tamże, s. 200.

3 Tamże, s. 201.
} 
represje pewnych rodzajów pamięci bywają nieskuteczne. Setna rocznica wiążąca się z mobilizacją zasobów finansowych, naukowych i artystycznych - opiera się na wspólnej i indywidualnej decyzji udziału w rytuale pamięci, którego znaczenie tworzone jest na różnych poziomach uczestnictwa w wydarzeniach i uroczystościach - od obecności po gotowość doświadczenia i rekonstrukcji traumatycznych przeżyć.

Przedstawienie traumy łączy się według Alexandra z tworzeniem nowej opowieści, która musi zawierać odpowiedzi na pytania dotyczące „charakteru cierpienia” - rany w psychice, ogromu, natury traumy; „charakteru ofiary” tożsamości, rodzaju i liczebności grupy społecznej doświadczającej traumy; "relacji między ofiarami traumy a szerszą publicznością" - umiejętności utożsamienia się z doświadczeniem poszkodowanej grupy; „przypisania odpowiedzialności" - określenia sprawcy - antagonisty ${ }^{4}$. Wiele z tych pytań zostało już postawionych w trakcie I wojny światowej i zaraz po niej. Zostały one zadane ponownie z bardziej krytycznej perspektywy w latach drugiej fali pamięci i dopełnione o opowieści i pytania dotyczące Holokaustu. Jednocześnie, jak pisze Alexander, nigdy nie udało się stworzyć jednoznacznego podziału między ofiarą a antagonistą, mimo ideologicznego dyskursu przeciwieństw i dychotomizacji w przedstawieniu wroga ${ }^{5}$. W wielu fikcyjnych i rzeczywistych dyskusjach kategorii antagonistów i sprawców było co najmniej kilkoro (np. wrogiem bywali Niemcy, niekompetentni dowódcy, spekulanci wojenni, niedoświadczeni żołnierze, warunki geologiczne), a wśród ofiar można wymienić zarówno całe narody (np. Anglicy, Szkoci, Francuzi, Kanadyjczycy), jak i jednostki i grupy, np. młodych niedoświadczonych żołnierzy wykorzystanych jako „mięso armatnie”.

W studium O społecznejkonstrukcji uniwersaliów Alexander wspomina o tym, że w okresie po I wojnie światowej nie udało się skutecznie przeprowadzić procesu uporządkowania traumy wojennej.Z powodu nieufności wobec propagandy i niemożności przypisania ról uczestnikom konfliktu (protagonisty i antagonisty) dominującą reakcją był relatywizm, a „poczucie rozczarowania i cynizmu" zostały wyrażone w ironii, która według Paula Fussella stała się głównym sposobem oddania doświadczenia I wojny światowej. Fussell Great War and Modern Memory, Oxford University Press, Oxford 2013, s. 82.

6 J. C. Alexander O społecznej konstrukcji uniwersaliów, w: Znaczenia społeczne. Studia z socjologii kulturowej, s. 234. 
twierdził, że właśnie dzięki ironii możliwa jest pamięć o traumatycznych wydarzeniach $\mathrm{i}$ jej zapis w uporządkowanych kategoriach (bez zastosowania ironii wydarzenia tworzyłyby bezkształtny strumień) ${ }^{7}$. Zarazem ironia sama w sobie podważała sposoby wyrażenia doświadczenia wojny w rozpoznawalnych i zwyczajnych kategoriach ${ }^{8}$. Taka sytuacja, z perspektywy traumy kulturowej, nie pozwoliła według Alexandra na wytworzenie mechanizmów "uporządkowania” „zdumiewających wstrząsów tamtych lat". Można uznać, że w związku z tym nie nastąpił kolejny proces po doświadczeniu traumy - etap jej rutynizacji, charakteryzujący się ponownym zintegrowaniem tożsamości zbiorowej, opadnięciem intensywności emocjonalnej, uspokojeniem i przetworzeniem $w$ rytuały pamięci ${ }^{10}$. Ten proces nie został ukończony w przypadku I wojny światowej i może wyjaśniać powroty - spontaniczne i instytucjonalne - do tematu I wojny światowej.

Narracja traumy kulturowej rozwija się w opozycji do narracji heroicznej. Ta relacja opisana została w kontekście Holokaustu jako zależność odwrotna. Narracja postępowa upamiętniająca heroizm i mit wyzwolenia umniejsza znaczenie Holokaustu i odwrotnie, trauma Holokaustu, historia o ofiarach opowiedziana przez ocalonych pomniejsza znaczenie opowieści bohatera ${ }^{11}$. Podobnie można uznać, że narracje heroiczne I wojny światowej zmniejszają znaczenie traumy zarówno indywidualnej, jak i pokoleniowej. Strategie ironii poniekąd przygotowują podłoże dla konfrontacji z traumą poprzez podważenie narracji heroicznych.

Konflikty i kontrowersje wokół tych narracji, mimo cenzury, widoczne były już w trakcie I wojny światowej ${ }^{12}$. Odżyły też w czasie drugiego boomu pamięci (second memory boom) i podczas dyskusji na temat sposobów upamiętniania obchodów stulecia I wojny światowej. Dyskusja taka rozwinęła się na przykład wokół publikacji artykułu autorstwa ówczesnego ministra

7 P. Fussell The Great War and Modern Memory, s. 31-32.

8 Por. J. Winter Remembering War: the Great War Between Memory and History in the Twentieth Century, Yale University Press, New Haven 2006, s. 118-124.

9 J.C. Alexander O społecznej konstrukcji uniwersaliów, s. 235.

10 J.C. Alexander Trauma kulturowa i tożsamość zbiorowa, s. 216.

11 J.C. Alexander O społecznej konstrukcji uniwersaliów, s. 298-299.

$12 W$ kontekście teatru $\mathrm{H}$. Kosok pisze o ścieraniu się różnorodnych wizji konfliktu w czasie wojny i roli cenzury w niedopuszczaniu np. sztuk pacyfistycznych do wystawienia na scenie. H. Kosok The Theatre of War: the First World War in British and Irish drama, Palgrave Macmillan, Basingstoke 2007, s. 174-177. 
edukacji Michaela Gove’a w „Daily Mail” (2014), która odrzucała krytyczną i prześmiewczą perspektywę zawartą chociażby w słynnym spektaklu i filmie muzycznym Och! Jaka urocza wojenka (1963/1969), oskarżając niektórych artystów o niezrozumienie istoty wojny lub wręcz o wyśmiewanie takich wartości jak honor, odwaga i patriotyzm ${ }^{13}$. Próba konsolidacji zbiorowego przeżycia jubileuszu i kolektywnego upamiętniania w ramach narracji oficjalnej ponownie - tak jak wcześniej przy drugim boomie pamięci - została rozbita na różne perspektywy i głosy, których ważnym elementem są projekty internetowe informujące na bieżąco o wydarzeniach rocznicowych i zamieszczające opracowane materiały dokumentalne w postaci podkastów, fotografii, artykułów $\mathrm{i}$ innych materiałów dostępnych $\mathrm{w}$ formie elektronicznej. Podkasty nie prezentują jednolitego punktu widzenia, przedstawiając różne oblicza wojny, takie jak wykorzystanie zwierząt w czasie konfliktu, praca kobiet czy losy mężczyzn odmawiających udziału w wojnie z powodów religijnych i ideologicznych ${ }^{14}$. Jubileusz poniekąd sztucznie mobilizuje przejawy pamięci i strategie upamiętniania. Sztucznie uaktywnia próby odkrycia i przyswojenia dawnych historii, poruszając przy okazji inne obszary traumy indywidualnej i społecznej.

Tak zwany „drugi boom pamięci” dotyczący I wojny światowej - jak już wcześniej zostało wspomniane - ugruntowany był w relacjach międzypokoleniowych. Żywotność historii, pisze Winter, w dużej mierze polega na znaczeniu historii rodzinnych, dla których stwarza szerszy i bardziej uniwersalny kontekst ${ }^{15}$. Wlatach 6o.i 70. relacje pokoleniowe między wnukami i dziadkami odnosiły się do wydarzeń I wojny światowej. Ponadto próba określenia traumy tej wojny przygotowała tło i częściowo narzędzia do zrozumienia i nazwania późniejszych traum ${ }^{16}$. W kontekście drugiego boomu pamięć o I wojnie światowej została przefiltrowana przez wydarzenia II wojny i Holokaustu, a jednolita narracja pierwszego boomu pamięci (którego koniec Winter datuje na lata 20. $\mathrm{XX}$ wieku) uległa rozwarstwieniu, fragmentacji, hybrydyzacji, rozszczepieniu

13

M. Gove Why does the left insist on belittling true British heroes?, "Daily Mail" 2.01.2014, http:// www.dailymail.co.uk (15.07.2014).

Na przykład strony internetowe Imperial War Museum lub First World War Centenary, http:// www.iwm.org.uk/history/voices-of-the-first-world-war, http://www.1914.org/ (15.07.2014).

5 J. Winter The generation of memory: reflections on the "memory boom" in contemporary historical studies, "Canadian Military History” 2001 No. 10 (3), art. 5, s. 62, http://scholars.wlu.ca/cmh/ vol10/iss3/5 (09.10.2017).

Tamże, s. 64. 
na różnorodne podmioty i perspektywy ${ }^{17}$.Znaczenie miała też różnica pokoleń - bunt wobec starszego pokolenia i jego zakłamania ${ }^{18}$. Drugi boom pamięci wprowadził zmianę także w podmiocie pamięci, jego/jej opowieści i słuchaczach. Według Wintera pamięć o wojnie została radykalnie przedefiniowana przez koncepcję nerwicy frontowej, która stała się w kontekście brytyjskim jedną z najważniejszych metafor, poprzez którą kolejne pokolenia definiowały i rozumiały relacje między pamięcią i tożsamością¹9.

Obchody stulecia wybuchu i zakończenia wojny stwarzają możliwość kolektywnego włączenia młodszego pokolenia w rytuały pamięci i współczucie wobec osób i wydarzeń, z którymi nie mają już bezpośredniej styczności. Procesy włączania najmłodszego pokolenia w upamiętnianie wojny odbywają się na poziomie zarówno kolektywnym, jak i indywidualnym, a ich ważnym elementem jest próba stworzenia powiązań pomiędzy pośrednią wiedzą o I wojnie światowej a współczesnym doświadczeniem wojny i innych wydarzeń traumatycznych. Jak pisze J. Ann Kaplan w Trauma Culture, traumy indywidualnej - jednostkowej - nie da się oddzielić od traumy zbiorowej. Trauma zależy od umiejscowienia, relacji w stosunku do wydarzenia, które może być przeżywane bezpośrednio, poprzez opowieści najbliższych lub zbiorowo pośrednio poprzez mediatyzację wydarzenia. Jako ilustrację wielopoziomowości doświadczenia traumy Kaplan opisuje swój własny przykład uczestnictwa w zbiorowym przeżywaniu traumy 11 września, która była blisko przestrzennie, ale w żaden sposób nie dotyczyła jej lub jej bliskich bezpośrednio. W współprzeżywaniu wydarzeń 11 września odżyła trauma II wojny światowej z okresu dzieciństwa, oparta na „umiarkowanie” drastycznych wydarzeniach, ale niezrozumiałych dla osamotnionego dziecka, więc przerażających ${ }^{20}$. Według Kaplan traumy nie da się wyleczyć, ale można ją „wykorzystać", aby zrozumieć katastrofy, których doświadczamy bezpośrednio lub poprzez innych, i aby odnaleźć w nich znaczenie. Kluczowe znaczenie w procesie, które Kaplan określa jako „przełożenie” (translation) traumy, ma sztuka ${ }^{21}$.

17 J. Winter Remembering War..., s. 18.

18 Tamże, s. 27.

19 Tamże, s. 60-61.

E.A. Kaplan Trauma Culture: the Politics of Terror and Loss in Media and Literature, Rutgers University Press, New Brunswick 2005, s. 3-4. 


\section{Trauma pośrednia i bycie świadkiem}

W procesie przełożenia traumy podstawowe znaczenie mają również aspekty traumy pośredniej i bycia świadkiem, które aktywowane są w konfrontacji z opowieścią ofiary lub jej wersjami artystycznymi. Jak twierdzi Kaplan, traumy pośredniej doświadczają nie tylko terapeuci, ale także np. widzowie i czytelnicy. W obu przypadkach tzw. pusta empatia może zarówno uniemożliwić odczuwanie cierpienia innych, jak i prowadzić do społecznego jego przeżywania ${ }^{22}$. Trauma pośrednia przeżywana przez terapeutów lub odbiorców przekazu artystycznego miewa działanie destrukcyjne, wywołując objawy charakterystyczne dla traumy bezpośredniej, ale też postrzegana jest pozytywnie jako prospołeczne zachowanie oparte na empatii ${ }^{23}$. Opisywane jako empatyczna nadpobudliwość lub wtórne zranienie, trauma pośrednia dotyczy jednostki - relacji między ofiarą bezpośrednią a jej odbiorcą. Kaplan pisze o byciu świadkiem - witnessing - jako o wykroczeniu ponad empatię i sensacyjność - prowadzącym do poczucia odpowiedzialności, chęci przeciwdziałania kolejnym przypadkom "niesprawiedliwości” i krzywdy. Bycie świadkiem oznacza doświadczenie emocji w taki sposób, że nie przysłania ono zrozumienia wydarzenia, jego przyczyny i konsekwencji. Jego zrozumienie pozwala na podjęcie kroków, aby wykluczyć ewentualność powtórzenia katastrofy. Kaplan łączy doświadczenie tego typu z odbiorem sztuki w ramach społeczności - ponad indywidualną traumą ${ }^{24}$. Społeczny wymiar bycia świadkiem dotyczy zbiorowego uznania przewinienia i cierpienia w ramach szerszej etycznej perspektywy, umożliwiającej upolitycznienie traumy. Odnosząc się do Dori Lauba, Kaplan podkreśla, że podstawą bycia świadkiem jest zgoda na wysłuchanie historii traumy - towarzyszenie ocalałemu w opowieści, współodpowiedzialność za wyłaniającą się prawdę ${ }^{25}$. Szczególnie istotny staje się trzeci poziom świadectwa - bycia świadkiem świadectwa - świadomość nieuchwytności wydarzenia i zniekształcenia pamięci o nim, a także zniekształcenia samej posttraumatycznej rzeczywistości ${ }^{\mathbf{2 6}}$. wstydliwy sekret wcześniejszego pokolenia zostaje przyswojony przez kolejne, które nie miało bezpośredniej styczności z wydarzeniem. Por. N. Abraham Notes On the Phantom: a Complement to Freud's Metapsychology, w: The Shell and the Kernel: Renewals of Psychoanalysis, 
Bycie świadkiem, jak pisze Shoshana Felman, oznacza gotowość stania się nośnikiem świadectwa - a zarazem nośnikiem traumatycznego wydarzenia. Świadek decyduje się świadomie podążać za wydarzeniem, nie tylko być jego ofiarą: jest to „podążanie za wydarzeniem [...] poprzez niejasności, poprzez ciemność i fragmentację, bez całkowitego zrozumienia jego zasięgu i wynikających z niego implikacji, bez możliwości jednoznacznego przewidzenia kierunku i ostatecznego celu tej podróży" ${ }^{\text {"27 }}$. Bycie świadkiem zakłada poddanie się ryzyku, konfrontacji z nieuchwytnością traumatycznego wydarzenia. Doświadczenie odbiorcy twórczości dotyczącej traumy w dużej mierze oznacza otwarcie się na traumę innych, gotowość na konfrontację z własną traumą i na wysiłek, który trzeba włożyć w krytyczne przepracowanie historii. Jak pisze Cathy Caruth, traumy innych stwarzają możliwość konfrontacji z własną traumą i zdania sobie sprawy z tego, że nasza własna trauma wplątana jest w złożoną sieć powiązań; sama możliwość wysłuchania czyjejś opowieści o ranie, pisze Caruth, jest dla nas zaskoczeniem i prowadzi nas do spotkania z innym ${ }^{\mathbf{2 8}}$.

\section{Trauma a sztuki performatywne}

Podążając za teorią Freuda, można uznać, że w ujęciu terapeutycznym teatr/ przedstawienie pełni ważną funkcję w procesach odgrywania i odreagowania (acting out) oraz przepracowania (working through) traumy, które dokonują się w przestrzeni publicznej i są doświadczeniem zbiorowym. Sztuki performatywne poniekąd przenoszą doświadczenie traumy indywidualnej w zbiorową, związaną z bezpośrednim udziałem w wydarzeniu i byciem jego świadkiem. Według Freuda osoba, która doświadczyła traumy w momencie wydarzenia, nie była w stanie doznać go w pełni, gdyż samo doświadczenie było zbyt intensywne lub przerażające. Afekt traumy zostaje po raz pierwszy przeżyty z opóźnieniem w innej sytuacji przywołującej doświadczenie traumy. Proces terapeutyczny według Freuda składa się z dwóch etapów: powtórzenia afektu wydarzenia traumatycznego poprzez jego odegranie

N. Abraham i M. Torok, oprac. i przeł. N.T. Rand. University of Chicago Press, Chicago 1994, s. 171-176; E. Lorek-Jezińska Hauntology and Intertextuality in Contemporary British Drama by Women Playwrights, Wydawnictwo Naukowe UMK, Toruń 2013, s. 30-32). Routledge, London 1992, s. 24. Przekład autorki artykułu. 
emocjonalne oraz przepracowania traumy. Powtórzenie afektu, jak twierdzi Freud, wiąże się z okresowym pogorszeniem stanu pacjenta i stosowaniem strategii uniku. Przepracowanie natomiast pozwala na zintegrowanie traumy i przywrócenie wydarzenia pamięci w bezpiecznym kontekście, $n p$. w ramach terapii mówionej ${ }^{29}$. O ile powtórzenie traumy można powiązać $\mathrm{z}$ aspektami przedstawienia i udziału w odgrywaniu scen związanych z wydarzeniem traumatycznym, o tyle przepracowanie opiera się na włączeniu wydarzenia w narrację - w opowieśćc ${ }^{30}$, która wykracza poza i ponad traumę i pozwala na powrót do „normalnego" życia.

Ze względu na zaangażowanie widza/uczestnika na kilku płaszczyznach jednocześnie interaktywne sztuki performatywne aktywują zarówno poziomy afektu i empatii charakterystyczne dla traumy pośredniej, jak i poziomy refleksji związanej z przyjęciem roli świadka samego świadectwa i krytycznej perspektywy. Możliwe jest więc to, co Alexander na przykładzie Holokaustu określa jako tworzenie „symbolicznego rozszerzenia poprzez dostarczenie współczesnym okazji do doświadczania emocjonalnego utożsamienia z cier-

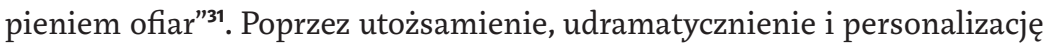
doświadczenia traumy zostają stworzone warunki „powtórnego” doświadczenia tragedii, które wydaje się nieodzownym elementem jego uniwersalizacji i które może przełożyć się na współczesne relacje między grupami społecznymi i jednostkami ${ }^{32}$. Natomiast poziomy świadomego zaangażowania jako świadka historii i traumy dotyczą zrozumienia i przeniesienia afektu i empatii na poziom krytyczny. To dzięki temu etapowi możliwe jest, jak twierdzi Kaplan, późniejsze przeciwdziałanie - niedopuszczenie do powtórzenia wydarzeń powodujących doświadczenia traumatyczne.

\section{Interaktywne projekty jubileuszowe}

Przedstawione w tej części projekty realizowane w ramach obchodów jubileuszowych rocznicy I wojny światowej rozpatrywane będą na trzech

29 S. Freud Remembering, Repeating and Working-through: Further Recommendations on the Technique of Psycho-analysis II (1914), w: The Standard Edition of the Complete Psychological Works of Sigmund Freud, vol. xii, ed. by and trans. J. Strachey, Hogarth Press, London 1950, s. 150-155.

Ch. Wald Hysteria, Trauma and Melancholia: Performative Maladies in Contemporary Anglophone Drama, Palgrave Macmillan, Basingstoke 2007, s. 99. 
poziomach dominujących w danym przedsięwzięciu - od afektu związanego z uczestnictwem, poprzez empatię świadka słuchającego historii, aż po trzeci poziom przenoszący traumatyczne doznania w gotowość do przeciwdziałania. We wszystkich analizowanych projektach te trzy poziomy istnieją lub mogą zaistnieć jednocześnie, ale zostały one wbudowane w jubileuszowe obchody według scenariusza zakładającego pewne formy uczestnictwa w pierwszej kolejności. Przykłady te zostały wybrane ze względu na ich interaktywny charakter i próby włączenia młodszego pokolenia w aktywny udział - z jednej strony w upamiętnianiu i refleksji nad przeszłością, a z drugiej - w wypracowywaniu gotowości do przeciwdziałania podobnym wydarzeniom ${ }^{33}$.

\section{Afekt}

Projekt artystyczny Shrouds of the Somme (2016) to instalacja zaprojektowana i wykonana przez artystę Roba Hearda. Zarówno sam proces tworzenia i przygotowania instalacji, jak i jej „zwiedzania” opiera się na przywołaniu afektu związanego ze stratą i niemożnością ukończenia rytuałów pochówku poległych w bitwie nad Sommą 72396 brytyjskich żołnierzy (w pierwszej fazie projektu 19240 ofiar), których ciał nigdy nie odnaleziono. Poprzez trwający kilka lat żmudny proces zawijania i zaszywania plastikowych figurek żołnierzy w białe całuny artysta doświadcza ogromu straty i skali tragedii. Zwiedzający wystawę, jak twierdzi Heard, w podobny sposób mają odczuwać rozmiar ofiary, zdać sobie sprawę, co oznaczają statystyki. Na poziomie tworzenia i odbioru projekt uaktywnia zarówno odegranie traumy i utraty bliskich, jak i jej przepracowanie w konstruktywnym procesie zbierania historii poległych. $\mathrm{Na}$ obu poziomach uczestnicy stają się „nośnikiem” traumy dzięki gotowości doświadczenia afektu związanego

Oczywiste jest, że Jubileusz zmobilizował także wiele bardziej tradycyjnych wydarzeń teatralnych dotyczących I wojny światowej, zarówno wystawień starszych dramatów, jak i premierowych spektakli. W wielu z nich reżyserzy łączyli oddanie hołdu i upamiętnianie z krytyką, satyrą i elementami humorystycznymi. Ze względu na wspomnianą wcześniej publikację artykułu Gove'a każde nowe przedstawienie zostało umieszczone w kontekście debaty nad sposobami i upolitycznieniem pamięci o wojnie. Jak twierdzi dramatopisarka i reżyserka Rachel Wagstaff, ważnym elementem debaty na temat przedstawienia wojny jest zrobienie wszystkiego, aby nie dopuścić do powtórzenia takiego cierpienia - głównie poprzez opowiedzenie historii młodym widzom. Zob. H. Williams The First World War on stage: lest we forget... the politics of war drama "Independent", 21.02.2014 http://www.independent.co.uk/arts-entertainment/ theatre-dance/features/the-first-world-war-on-stage-lest-we-forget-the-politics-of-wardrama-9144206.html (20.09.2017). 
$\mathrm{z}$ traumą i aktywnego udziału w procesie rekonstrukcji traumatycznego wydarzenia.

Według artysty głównym celem projektu było „ufizycznienie” - ucieleśnienie liczby, unaocznienie straty, której kiedyś doświadczyli bliscy na poziomie indywidualnym i zbiorowym. Efekt emocjonalny miał być osiągnięty zarówno w procesie tworzenia, jak i kontaktu widza z instalacją, w odniesieniu do jednostki i całej grupy zwiedzających. Według opisu projektu każda dwunastocalowa figurka miała nadane imię i nazwisko z listy poległych a jej ciało zostało ułożone w sposób, który miał zobrazować zarówno wyjątkowy, niepowtarzalny charakter zmarłego, jak i jednostkowy, indywidualny charakter samej śmierci ${ }^{34}$.Zwiedzający instalację także doświadczali masowości śmierci i anonimowości ofiar, które z odległości przypominały małe sklonowane płócienne lalki ${ }^{35}$. Z powodu niewielkiego rozmiaru figurki z jednej strony trywializują postaci żołnierzy, ale z drugiej wywołują współczucie wobec ich bezbronności. Ukazanie indywidualnego cierpienia w momencie śmierci poprzez modelowanie kształtu figurek - próba przedstawienia nienaturalnego położenia martwych ciał - tworzy efekt przerażenia i niepokoju (unheimlich) ${ }^{36}$ wynikający z nałożenia na siebie sfery zwyczajności (lalki) i tabu śmierci ${ }^{37}$. Komentarz reportera $\mathrm{z}$ materiału filmowego ITV pogłębia ten dysonans, nazywając spontaniczne udekorowanie figurek przez zwiedzających kwiatami - adoptowaniem figurek/zmarłych ${ }^{38}$. Głosy anonimowych widzów podkreślają emocjonalną intensywność projektu i uczucie niepokoju, którego doświadczyli. Większość z nich zaznacza w swych komentarzach

Na podstawie opisu projektu zaczerpniętego z oficjalnej strony Shrouds of the Somme https:// shroudsofthesomme.com/our-story/ (10.09.2017).

W Internecie dostępne jest nagranie obrazu przy użyciu drona ukazujące zaskakujący obraz instalacji z większej odległości, https://www.youtube.com/watch?v=IUgt5/k7Bw8 (10.09.2017).

S. Freud The Uncanny (1919), trans. J. Strachey. w: Literary Theory: an Anthology, ed. by J. Rivkin, M. Ryan, Blackwell, Malden 1999, s. 154-167. Efekt niepokoju i niesamowitości wykorzystany został też w innym projekcie We're here because we're here, w którym 1 sierpnia 2016 roku w wielu miastach Wielkiej Brytanii ochotnicy przebrani w mundury z I wojny światowej i przedstawiający poległych żołnierzy pojawili się bez zapowiedzi w różnych miejscach publicznych, podążając do miejsca zbiórki, gdzie odśpiewali znaną piosenkę śpiewaną przez żołnierzy w okopach, https://becausewearehere.co.uk/ (10.09.2017).

Sama postać lalki uważana jest za potencjalne źródło niepokoju i przerażenia wynikającego z podobieństwa do człowieka i zarazem swojej nieożywionej natury. Por. E. Jentsch w: S. Freud The Uncanny, s. 157. Materiał ITV, https://www.youtube.com/watch?v=zdgz_-kO-Z8 (10.09.2017). 
ogrom poświęcenia żołnierzy w czasie bitwy ${ }^{39}$. W oficjalnych materiałach dominuje narracja o ofierze złożonej przez młodych ludzi, będąca przedłużeniem narracji bohaterskiej.W dużej mierze projekt polega na powtórzeniu rytuału pamięci, który pierwotnie i oficjalnie dokonał się w latach 30. XX wieku przy konstrukcji The Thepval Memorial, pomnika pamięci zaginionych w czasie bitwy nad Sommą. W samym zamyśle jubileuszowego projektu najważniejsze jest zrekonstruowanie ogromu straty i bezsilności wobec anonimowości ofiar, a więc narracja ocalonego. Można uznać, cytując Alexandra, że Shrouds of the Somme jest próbą „zachowania świadectwa ocalonego", który ma „podtrzymać tragiczny dramat traumy, pozwalający jeszcze szerszej publiczności na odkupienie poprzez cierpienie"40. Ten wymiar świadectwa jest kontynuowany w dalszym etapie projektu polegającym na zebraniu materiałów wśród bliskich poległych ofiar, którzy mogą udostępnić swoje historie, pamiętniki, fotografie dotyczące żołnierzy na stronie internetowej jako przygotowanie do prezentacji instalacji w Londynie w 2018 roku z liczbą figurek odpowiadającą liczbie ciał pochowanych wokół The Thiepval Memorial ${ }^{41}$. Zmobilizowanie wysiłku włożonego w gromadzenie dokumentów, pamięć i refleksję rodzin i kolejnych pokoleń poprzez udział w projekcie dopełnia procesy personalizacji śmierci, kompensacji wobec anonimowości symbolicznych grobów i może być uznane za substytut rytuałów pochówku przeniesiony z miejsca

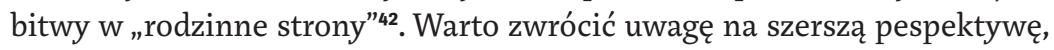
która wyłania się spod nacjonalistycznego dyskursu - przeniesienie obrazu dawnej traumy na współczesne doświadczenie wojny, nie tylko ofiar konfliktów wśród Brytyjczyków, ale wśród wszystkich narodowości, które pojawia się w jednym z komentarzy jako refleksja na temat znaczenia projektu ${ }^{43}$. Gotowość na poddanie się traumatycznemu doznaniu idzie tutaj w parze ze świadomością znaczenia uniwersalnego, wykraczającego ponad historyczne wydarzenie.

39 Na podstawie głosów nagranych jako podkład dźwiękowy obrazu z instalacji. https://www. youtube.com/watch?v=g5MSxvxl73Y (10.09.2017).

40 J.C. Alexander O społecznej konstrukcji uniwersaliów, s. 300.

41 Zob. http://blog.cwgc.org/thiepval-stories (10.11.2017).

42 Na stronie projektu został zamieszczony cytat z wypowiedzi twórcy instalacji Boba Hearda: "All these men are lying on the battlefield to this day and in some small way I would like to bring them home", https://shroudsofthesomme.com/our-story/ (10.11.2017).

43 Na podstawie głosów nagranych jako podkład dźwiękowy obrazu z instalacji. https://www. youtube.com/watch?v=g5MSxvxl73Y (10.11.2017). 


\section{Empatia i trauma pośrednia}

Spektakl Children of the Great War zrealizowany przez teatr Age Exchange w 2014 roku składa się ze scen przedstawiających historie 125 londyńskich rodzin oparte na wspomnieniach starszych osób, które były dziećmi w czasie I wojny światowej44. Historie przez nich opowiedziane, odegrane z pomocą grupy nastoletnich aktorów, przedstawiają ich własne wspomnienia o ojcach i dziadkach lub opowieści ich matek. Spektakl był częścią większego programu gromadzenia i archiwowania rodzinnych historii dotyczących I wojny światowej, w ramach którego zostały zorganizowane także wystawa i filmowa instalacja ${ }^{45}$. Age Exchange to teatr wspomnień, którego celem jest nawiązanie kontaktu między pokoleniami starszych osób i rówieśników ich wnuków. Projekty międzypokoleniowe mają z reguły charakter edukacyjny, a ich punktem wyjścia są nagrywane wywiady przeprowadzone przez nastolatków ze starszymi osobami. Na podstawie zebranych materiałów tworzony jest spektakl we współpracy z osobami z obu pokoleń w kameralnej atmosferze w obecności rodzin i znajomych ${ }^{46}$.

W projekcie Dzieci Wielkiej Wojny opowieści o ojcach i dziadkach walczących w I wojnie światowej przedstawiają różne doświadczenia i perspektywy. Osoby starsze występujące na scenie z trudem opanowują wzruszenie i emocjonalne zaangażowanie w opowiadane historie, czasami w opowieści włącza się osoba pomocnika, który wspomaga i komentuje sam proces opowiadania; niektóre sceny odgrywane są przez młodych aktorów, większość jednak jest opowiedziana w formie monologów i rozmów między członkami dwóch pokoleń. Opowieści bywają oparte na własnych reminiscencjach z dzieciństwa, kiedy to jako dzieci aktorzy stawali się świadkami efektu traumy (np. w przypadku nerwicy wojennej i izolacji cierpiącego ojca) lub słuchaczami pozytywnej historii ocalonego (np. historia inwalidy wojennego, który zdołał powrócić częściowo do pracy estradowej i odnaleźć swe miejsce w społeczeństwie). Jedna z opowieści przedstawia bezsenne noce ojca po powrocie z frontu, które stają się okazją do rozmów z synem i przekazania świadectwa wydarzeń wojennych. Interesujący jest ambiwalentny stosunek do decyzji dowódcy i spotkania z wrogiem na ziemi niczyjej, ponad animozjami

44 Na podstawie zapisu video spektaklu udostępnionego przez teatr na kanale Youtube. https:// www.youtube.com/watch?v=bjll-Cqj6wE (10.11.2017).

Zob. http://www.age-exchange.org.uk/cotgw/ (10.11.2017).

46 M. Prendergast, J. Saxton Applied Theatre: International Case Studies and Challenges for Practi-
ce, Intellect, Bristol 2009, s. 169. 
i podziałami. Ten sam żołnierz pozostaje sceptycznie nastawiony do udziału w II wojnie światowej, mając w pamięci okropieństwa I wojny. Nie brakuje też historii heroicznych, upamiętniających odwagę, brawurę i poświęcenie żołnierzy, połączone z indywidualnym poczuciem dumy z członka rodziny, który otrzymał odznaczenie za bohaterską walkę. Jedna ze scen opiera się na naprzemiennym czytaniu autentycznych listów adresowanych do matki, pisanych przez dwóch synów mniej więcej w tym samym okresie. Jest w nich dużo ironii, humoru, nadziei i lekkości, która w konfrontacji z odegraną sceną otrzymania listów informujących matkę o ich śmierci tworzy silny efekt ironiczny i emocjonalny. W jednej z rekonstruowanych rozmów między ojcem-żołnierzem a synem (w projekcie międzypokoleniowym osoba starsza, która była dzieckiem w czasie wojny, wciela się w rolę ojca, a nastolatek lub nastolatka w rolę syna lub córki) ojciec wyjaśnia dlaczego nadał swojemu synowi imiona swoich kompanów z czasu wojny. Tym sposobem młodsze pokolenie zostaje poniekąd wpisane w podtrzymywanie pamięci i staje się nośnikiem wspomnień i traumy wojennej.

W spektaklu dokonuje się symboliczne przeniesienie określenia „dzieci I wojny światowej” na współczesne pokolenie nastolatków, którzy dzięki odgrywaniu ról dzieci z okresu I wojny światowej przejmują historie starszego pokolenia. Poprzez połączenie narracji z rekonstrukcją i prezentacją wydarzeń uczestnicy projektu angażują się zarówno w doświadczenie wojny, jak i w jej oswojenie w opowieści adresowanej do innych, a więc wymagającej odpowiedniej kompozycji, stopniowania napięcia, dodania zakończenia i innych zabiegów narracyjnych. Za sprawą gotowości na opowiedzenie historii, przeżycia wraz z podmiotem traumatycznych wydarzeń, stania się i świadkiem, i nośnikiem traumatycznych wspomnień poszerza się krąg osób bardziej bezpośrednio związanych z traumą wojenną (bardziej, gdyż jest to już kolejny poziom opowieści). Projekt teatru Age Exchange odbudowuje osłabione relacje międzypokoleniowe, poniekąd sztucznie przywołując wymiar traumy kulturowej. Godne uwagi jest zaangażowanie w projekt młodzieży z różnych środowisk etnicznych, co zjednej strony można uznać za zaproszenie do udziału we wspólnocie poprzez gotowość do przekazania wydarzenia traumatycznego istotnego dla docelowej społeczności. Z drugiej strony poprzez udział w głównie europejskiej historii uczniowie przejmują traumę nie swojej grupy społecznej, przyczyniając się do osłabienia relacji ze starszym pokoleniem w ich własnych rodzinach ${ }^{47}$.

47 O istotnym znaczeniu włączenia wielokulturowych społeczności w obchody stulecia I wojny światowej mówił m.in. Suba Das, reżyser przedstawienia na podstawie dramatu Wipers, któ- 


\section{Odpowiedzialność świadka}

Głównym celem projektu adresowanego do uczniów szkół średnich - National Schools Programme: Oh, What a Lovely War (2013-2014) realizowanego w 50. rocznicę słynnego spektaklu Theatre Workshop (1963) w reżyserii Joan Littlewood było zachęcenie młodych ludzi do krytycznego spojrzenia na I wojnę światową przez pryzmat współczesnych konfliktów i wojen ${ }^{48}$. Projekt składał się z dwóch etapów: konkursu krótkich filmowych zwiastunów planowanych spektakli i konkursu jednoaktówek na temat wojny, nawiązujących do kontrowersyjnego spektaklu. Zwycięskie prace i minispektakle prezentowane były w formie krótkich filmów na stronie internetowej projektu (oraz na kanale Youtube). Najlepsze miały zostać wystawione na deskach teatru the Theatre Royal Stratford East, w którym prezentowany był pierwotny spektakl, tuż przed głównym wydarzeniem, którym było wznowienie sztuki po latach. W ramach programu przygotowane były też dodatkowe materiały edukacyjne dostępne online, takie jak wywiady, animacje, miniwykłady, broszury. W serii tych tzw. cyfrowych podarunków łatwo dostępnych dla młodego pokolenia, uczestnicy byli zachęcani do aktywnego i krytycznego udziału w upamiętnianiu I wojny światowej, do podważania narracji heroicznej i patriotycznej, obnażania manipulacji politycznych, identyfikacji z żołnierzem jako ofiarą - nie tyle wroga, co niekompetencji przywódców i bezwzględnych kalkulacji spekulantów wojennych.

Projekt na różnych etapach zachęcał uczestników do dwóch podstawowych form zaangażowania: po pierwsze, odpowiedzi na pytanie, co dla nich oznacza wojna, i po drugie, krytycznego myślenia oraz stawiania pytań i podważania utartych odpowiedzi (idąc za przykładem strategii użytych

rego autorem jest Ishy Din. W wywiadzie podkreślał, jak bardzo w obecnym momencie społecznym i politycznym potrzebne jest odkrywanie zapomnianych, niedopowiedzianych historii udziału mniejszości etnicznych, np. ochotników z Indii i Azji, w działaniach wojennych. Według reżysera tego typu historie otwierają możliwość udziału w narracji o wojnie dla mniejszości etnicznych, które czują się częściowo wykluczone z uczestnictwa jubileuszu, co jest szczególnie ważne w przypadku edukacji szkolnej, https://www.youtube.com/watch?v=szYKEPLfXzM, https://www.youtube.com/watch?v=yAi6xVaTj6Y (5.12.2017).

O projekcie tym pisałam w artykule The Legacy of Oh, What a Lovely War!: Remembering and Re-Imagining the First World Warw: Conflicting Discourses, Competing Memories: Commemorating the First World War, ed. by A. Branach-Kallas, N. Sabiniarz, N. Strehlau. Wydawnictwo Naukowe UMK, Toruń 2015, s. 81-93. Materiały archiwalne wykorzystywane w obecnym i powyższym artykule nie są już dostępne w Internecie, stąd też podane poniżej przypisy odnosić się będą do stanu z roku 2014. 
w Oh, What a Lovely War! ${ }^{49}$. Większość zwycięskich projektów łączyło w sobie włożenie dużego wysiłku w próbę odpowiedzi na pierwsze pytanie przy jednoczesnym sceptycznym i ironicznym stosunku do dostępnych środków wyrazu i utartych sposobów prezentacji wojny. Niektóre spektakle (np. Join the army, see the world - St Mary's Catholic School ${ }^{50}$ ) bezpośrednio nawiązywały do debaty nad dopuszczalnymi formami upamiętniania I wojny światowej, zapoczątkowanej przez ministra Gove'a, przedstawiając polityka jako jedną z wyśmiewanych $\mathrm{w}$ spektaklu postaci w scenie na temat ideologizacji nauczania historii w szkołach. Formuła projektu zakładała udział młodego pokolenia w działaniach na rzecz pamięci o I wojnie światowej w krytycznym ujęciu, ze świadomością konstruktywności wojennych narracji. Wzorując się na spektaklu Theatre Workshop, uczniowie wykorzystywali strategie podważania i kwestionowania autorytetów i świętości, aby stworzyć krytyczną wizję wojny z perspektywy młodego człowieka. Konfrontacja z tematem I wojny światowej stała się okazją dla próby zrozumienia różnic i podobieństw między pokoleniami, znaczenia i zarazem bezsensu wojny i cierpienia, a także procesów przywłaszczania i tworzenia znaczeń wokół wydarzeń historycznych. Można uznać, że podstawowym celem projektu było doprowadzenie do poziomu krytycznego stawania się świadkiem świadectwa, ze świadomością problematyczności dotarcia do pierwotnego wydarzenia i konieczności przeciwdziałania przyszłym wojnom i konfliktom.

\section{Podsumowanie}

Wśród ogromu wydarzeń artystycznych poświęconych upamiętnianiu I wojny światowej w jej setną rocznicę interaktywne projekty teatralne i performatywne odgrywają szczególną rolę w procesach konstruowania traumy zbiorowej. Projekty omówione w niniejszym artykule zachęcają uczestników do odbudowywania powiązań między pokoleniami, rekonstrukcji historii rodzinnych oraz odniesienia osobistych doświadczeń do traumatycznych przeżyć z okresu I wojny światowej. Częściowo sztucznie przywoływane więzy i rekonstruowane relacje między pokoleniami mają na celu społeczne zakotwiczenie boomu pamięci instytucjonalnie wywołanego w ramach setnego

49 M. Dennehy Oh What a Lovely War: resource pack, 2013. http://issuu.com/stratfordeast/docs/ oh_what_a_lovely_war_education_pack (02.09.2014).

50 St. Mary's Catholic School Join the army, see the world!, 2014, http://www.stratfordeast.com/ schools-programme-curtain-raiser-performances (02.09.2014). 
jubileuszu wojny. Projekty analizowane w artykule stworzyły platformę, na której publicznie zostały opowiedziane osobiste historie, wywodzące się z mikrohistorii rodzinnych, w ramach której uczestnicy mieli okazję poznać wspomnienia i doświadczenia innych osób, zrozumieć i unaocznić rozmiar ofiary i cierpienia poległych oraz skalę straty i bólu ocalałych. Te przedsięwzięcia artystyczne oparte były na dzieleniu się i wysłuchaniu nawzajem swoich historii, spotkaniu z innymi ludźmi poprzez pamięć o pokoleniu dziadków i pradziadków. Szczególnie znaczące są strategie integrowania z rytuałami pamięci środowisk mniejszości narodowych i etnicznych poprzez przyjęcie przez nich roli symbolicznego pokolenia dzieci wojny lub włączenie w narracje publiczne wcześniej pomijanych lub zapomnianych historii udziału w konflikcie żołnierzy spoza Europy.

We wszystkich projektach przywołane były opisywane przez Cathy Caruth dwa kryzysy - kryzys śmierci i kryzys życia, w konfrontacji między dwiema historiami nie do zniesienia - historią śmierci i historią jej przeży$\mathrm{cia}^{51}$. Najbardziej widoczne są one w przypadku projektu Shrouds of the Somme, gdzie rytuał ponownego pochówku łączy w sobie unaocznienie śmierci i cierpienia poległych z bólem ocalałych. Projekt Children of the Great War przeplata historie śmierci i traumy żołnierza z historiami powrotu do normalnego życia. W programie Oh, What a Lovely War! relacje między tymi dwiema historiami zbudowane są na podłożu ironii i sarkazmu. Obie traumy w analizowanych projektach poddane są zarówno procesom wywołania lub przywołania afektu pierwotnego wydarzenia, jak i przepracowania go w opowieści lub krytycznej ocenie. Na każdym etapie projekty te wymagają od uczestników znacznego zaangażowania emocjonalnego, otwartości na Innego i gotowości do aktywnego doświadczenia (stania się nośnikiem traumy), a także dalszego przemyślenia swoich reakcji (bycia świadkiem świadectwa).

Znamienne dla wszystkich wymienionych w artykule projektów, które opierają się w swym założeniu na bezpośrednim aktywnym uczestnictwie, jest ich jednoczesne funkcjonowanie w przestrzeni cyfrowej. Projekty te rozwijają się na platformach internetowych i zachęcają do interakcji za pośrednictwem mediów elektronicznych. W ten sposób ich zasięg znacznie wykracza ponad bezpośrednich uczestników wydarzeń. Analizowane projekty zaangażowane są w procesy gromadzenia i archiwizacji historii i dokumentów, a zarazem same podlegają procesom archiwizacji i mediatyzacji, przyjmując formę poddającą się dalszej cyrkulacji. W ten sposób można 
stwierdzić za Alexandrem, że „pozwalając członkom szerszej zbiorowości uczestniczyć w bólu innych, traumy kulturowe poszerzają obszar społecznego porozumienia i współczucia oraz dostarczają ważnych dróg dla nowych form społecznego zjednoczenia"52 - w tym przypadku wokół jubileuszu I wojny światowej.

\section{Abstract}

\section{Edyta Lorek-Jezińska}

NICOLAUS COPERNICUS UNIVERSITY (TORUŃ)

Mobilizing Memory: Cultural Trauma and the Centenary of World War I Intergenerational Theatre Projects

Lorek-Jezińska examines British celebrations of the centenary of World War I in interactive theatre and artistic projects, focusing on their function in constructing and reviving the cultural trauma. She investigates strategies for including the younger generation in centenary celebrations and commemorations - strategies based on mobilizing participants' compassion, empathy and readiness to become the medium of testimony. In this way the third memory boom stimulated by the centenary revives the intergenerational relations that formed the basis of the earlier World War I memory boom, additionally including social groups that had previously been disregarded or excluded from this process.

\section{Keywords}

cultural trauma, World War I, centenary, interactive theatre projects

52 J.C. Alexander Trauma kulturowa i tożsamość zbiorowa, s. 217. 